\title{
WISATA HALAL DI GILI TRAWANGAN LOMBOK UTARA
}

\author{
Muh. Baihaqi \\ Universitas Islam Negeri Mataram \\ baihaqi@uinmataram.ac.id
}

\begin{abstract}
This study aims to determine the implementation of halal tourism on Gili Trawangan and to determine the response of tourism actors to the implementation of Perda No. 2 of 2016 concerning Halal Tourism in the Gili Trawangan Region. This type of research is descriptive qualitative which takes data through observation, interviews and documentation. The concept of halal tourism on Gili Trawangan cannot be fully implemented in a short time, but it takes a long time because it is feared that it will have an impact on the number of foreign tourists visiting, especially those from Europe. The tourism actors respond to the application of halal tourism on Gili Trawangan with a different response. Some tourism operators accept the concept of halal tourism applied in Gili Trawangan, some disagree with offering an alternative to the regulation being implemented in Gili Air or Gili Meno with the concept of shari'ah beach tourism. Some stated that the Halal Tourism Law is not suitable at all applied in coastal areas and only suitable for urban tourism.
\end{abstract}

Keywords: Perda, halal tourism, response, implementation, Gili Trawangan.

\begin{abstract}
Abstrak
Penelitian ini bertujuan untuk mengetahui implementasi wisata halal di Gili Trawangan serta untuk mengetahui respon pelaku wisata terhadap implementasi Perda No. 2 Tahun 2016 Tentang Wisata Halal di Kawasan Gili Trawangan. Jenis penelitian ini adalah kualitatif deskriptif yang mengambil data melalui observasi, wawancara dan dokumentasi. Konsep wisata halal di Gili Trawangan tidak dapat diimplementasikan secara utuh dalam waktu yang singkat, namun membutuhkan waktu yang lama karena dikhawatirkan akan berdampak pada jumlah kunjungan wisatawan mancanegara terutama yang berasal dari Eropa. Para pelaku wisata merespon penerapan wisata halal di Gili Trawangan dengan respon yang berbeda. Sebagian pelaku wisata menerima konsep wisata halal diterapkan di Gili Trawangan, Sebagian lagi tidak setuju dengan menawarkan alternatif Perda tersebut diterapkan di Gili Air atau Gili Meno dengan konsep wisata pantai syari'ah. Sebagian lagi menyatakan Perda Wisata Halal tidak cocok sama sekali diterapkan di kawasan pantai dan hanya cocok diterapkan pada wisata perkotaan.
\end{abstract}

Kata Kunci: Perda, wisata halal, respon, implementasi, Gili Trawangan. 


\section{PENDAHULUAN}

Dinobatkannya Lombok sebagai pemenang pada World Halal Travel Summit pada 2015 lalu merupakan babak baru perkembangan pariwisata di Nusa Tenggara barat. Pariwisata halal adalah konsep yang sedang dibidik oleh segmen pariwisata dari berbagai negara. Pariwisata halal adalah pariwisata yang menikmati segala kekayaan alam dan tempat wisata di setiap negara namun dibalut dalam esensi syariah dan tidak hanya ditargetkan pada wisawatan muslim saja, namun terbuka untuk semua kalangan karena pariwisata syariah bukanlah pariwisata religi (Islam) tapi menikmati berbagai dengan konsep syariah yang memberikan manfaat tidak hanya kepada pengelola bisnis, namun manfaatnya bisa dirasakan oleh penikmat wisata dan lingkungan sekitar dan terjamin keberlangsungannya. Esensi syariah tidak hanya mengkomsusi makanan dan minuman dalam konteks halal, halal disini juga dijelaskan mengapa makanan tersebut dikatakan halal dan layak dikomsumsi.

Potensi halal tourism yang dimiliki oleh Provinsi NTB sangat besar. Provinsi NTB merupakan salah satu model wisata halal di Indonesia. Pengembangan halal tourism di Provinsi NTB terus dilakukan melalui upaya-upaya seperti Peraturan Daerah Pariwisata Halal yang merupakan pertama di Indonesia yaitu Peraturan Daerah Provinsi NTB No.2 Tahun 2016 tentang Pariwisata Halal. Perda ini ditandatangani oleh Gubernur Nusa Tenggara Barat H.M. Zainul Majdi tertanggal 21 Juni 2016.

Peraturan Daerah Provinsi NTB No.2 Tahun 2016 tentang Pariwisata Halal muncul sebagai respon pemerintah daerah terhadap dua penghargaan yang diraih oleh NTB dalam ajang The World Halal Travel Summit/Exhbition 2015 (WHTS15) di Abu Dhabi, Uni Emirate Arab (UEA) yang memberikan penghargaan kepada Lombok Nusa Tenggara Barat dua penghargaan sekaligus, yakni World's Best Halal Tourism Destination dan World's Best Halal Honeymoon Destination. Terkait dengan dua penghargaan itu, Pemerintah Daerah menyikapi dengan menetapkan Peraturan Gubernur No. 51 Tahun 2015 tentang Wisata Halal. Kemudian oleh DPRD NTB melalui Usul Inisiatif mengajukan Rancangan Peraturan Daerah tentang Pariwisata Halal. Setelah melalui proses pembahasan, maka DPRD NTB menyetujui menjadi Peraturan Daerah tentang Pariwisata Halal yakni Peraturan Daerah Provinsi NTB No.2 Tahun 2016 tentang Pariwisata Halal (Hidayaatullah, 2016).

Peraturan Daerah tentang Pariwisata Halal tersebut sampai saat ini menjadi sebuah materi diskusi menarik terutama ketika ditendensikan dengan beberapa destinasi wisata di Nusa Tenggara Barat yang notabene sangat sulit untuk menerapkan peraturan tersebut, salah satunya di kawasan wisata Gili Trawangan di Kabupaten Lombok Utara. Sebagaimana diketahui, kawasan wisata Gili Trawangan adalah salah satu surga wisata di Nusa Tenggara Barat di mana para wisatawan, terutama wisa- 
tawan manca negara yang bergaya hidup sebagaimana layaknya hidup di negara mereka yang berbeda dengan corak dan budaya ketimuran khususnya di Nusa Tenggara Barat yang kental dengan budaya islami.

Perilaku-perilaku seperti berpakaian dengan bikini, kafe-kafe yang menyajikan minuman keras merupakan pemandangan yang biasa ditemukan di sepanjang pantai. Bukan hanya di bibir pantai, pemandangan seperti itu bahkan menyebar di setiap sudut kawasan Gili Trawangan. Selain dua persoalan tersebut, di sekitar destinasi juga tidak tersedia fasilitas ibadah khususnya bagi pengunjung muslim kecuali sebuah masjid yang berada di tengah kampung dan hanya bisa dijangkau oleh para pengunjung yang dekat dengan masjid saja.

Di sisi lain, penerapan Peraturan Daerah No. 2 tahun 2016 tentang wisata halal dapat menjadi penghalang bagi sebagian wisatawan untuk berkunjung karena akan membatasi kebebasan mereka dalam menikmati kegiatan berwisata. Ini akan mengakibatkan jumlah wisatawan berkurang akibat penerapan Perda tersebut, maka secara otomatis akan mengurangi pendapatan bagi para pelaku wisatawan baik guide, travel, termasuk para pedagang di sekitaran kawasan Gili Trawangan.

\section{LANDASAN TEORI}

\section{Respon}

Respon berasal dari kata response, yang berarti balasan atau tanggapan (reaction). Respon adalah istilah psikologi yang digunakan untuk menamakan reaksi terhadap rangsang yang di terima oleh panca indra. Hal yang menunjang dan melatarbelakangi ukuran sebuah respon adalah sikap, persepsi, dan partisipasi. Respon pada prosesnya didahului sikap seseorang karena sikap merupakan kecendrungan atau kesediaan seseorang untuk bertingkah laku jika menghadapi suatu rangsangan tertentu. Jadi, berbicara mengenai respon atau tidak respon terlepas dari pembahasan sikap. Respon juga diartikan sebagai suatu tingkah laku atau sikap yang berwujud baik sebelum pemahaman yang mendetail, penelitian, pengaruh atau penolakan, suka atau tidak suka serta pemanfaatan pada suatu fenomena tertentu (Sarwono, 1998).

\section{Wisata Halal}

Secara harfiah wisata berasal dari bahasa Sansekerta yang berarti perjalanan berpergian (Kencana, 2019). Dari pengertian ini wisata berarti perjalanan yang dilakukan dari suatu tempat yang ingin dikunjungi, yang menurut Bahasa Ingggris di sebut Tour. 
Dalam Bahasa Arab, perjalanan wisata atau pariwisata sering diistilahkan dengan kata as-siyahah yang diambil dari ungkapan saaha al-maa' (air mengalir, mencair, meleleh). Ungkapan tersebut digunakan menyebut air yang mengalir dan berjalan di atas permukaan tanah, kemudian digunakan untuk konteks manusia yang berarti berpergian di atas permukaan bumi dalam rangka beribadah, meningkatkan kesalehan atau tanpa tujuan apapun (Bahamman, 2012). Dengan demikian, as-siyahah identik dengan melancong.

Wisatawan muslim merupakan segmen baru yang sedang berkembang pesat dalam industri pariwisata. Menjelajahi dunia seperti wisatawan lain dengan tidak mengorbankan kebutuhan dasar mereka berupa pemenuhan makanan halal dan kemudahan pelaksanaan ibadahnya berupa shalat. Jadi, secara umum pariwisata syari'ah dan pariwisata konvensional tidak beda, hanya kebutuhan terhadap paket wisata, akomodasi, makanan dan minuman memenuhi ketentuan nilai-nilai Islam dimana hal ini dapat juga dinikmati oleh semua kalangan karena secara 'generic' tidak berbeda.

Istilah wisata halal dalam literatur pada umumnya disamakan dengan beberapa istilah seperti Islamic tourism, syari'ah tourism, halal travel, halal friendly tourism destination, Muslim-friendly travel destinations, halal lifestyle, dan lain-lain. Menurut Jaelani, dari sisi industri, wisata syariah merupakan suatu produk pelengkap dan tidak menghilangkan jenis pariwisata konvensional. Sebagai cara baru untuk mengembangkan pariwisata Indonesia yang menjunjung tinggi budaya dan nilai-nilai Islami tanpa menghilangkan keunikan dan orisinalitas daerah.

\section{METODE}

Jenis penelitian ini adalah kualitatif yaitu jenis penelitian yang menghasilkan penemuan-penemuan yang tidak dapat dicapai dengan menggunakan prosedurprosedur statistik atau dengan cara kuantifikasi lainnya. Data-data dalam penelitian ini diperoleh melalui metode observasi, wawancara dan dokumentasi. Sumber data penelitian ini adalah para pelaku wisata di Gili Trawangan, foto, video, dokumen pribadi, memo ataupun dokumen resmi lainnya (Maleong, 1990). Jenis penelitian ini adalah penelitian deskriptif yaitu jenis penelitian yang memberikan gambaran atau uraian atas suatu keadaan sejernih mungkin tanpa ada perlakuan terhadap obyek yang diteliti (Kountur, 2004). 


\section{HASIL DAN PEMBAHASAN}

\section{Fasilitas Wisata Halal di Gili Trawangan}

1). Arah Kiblat di Kamar Hotel.

Sebagai implementasi Peraturan Daerah Nomor. 2 Tahun 2016 tentang Pariwisata Halal, semua hotel yang berada di kawasan Gili Trawangan memasang fasilitas arah kiblat di setiap kamar hotel.

Arah kiblat di kamar hotel memang hanya dibutuhkan oleh tamu muslim yang ingin melakukan ibadah shalat di dalam kamar, sedangkan yang non-muslim jelas tidak memerlukan itu. Meskipun wisatawan yang berkunjung ke Gili Trawangan mayoritas yang non-muslim, namun arah kiblat itu harus ada karena tidak menggangu kenyamanan mereka.

Sebagaimana yang dituturkan oleh Pak Agus, seorang karyawan Villa Ombak Resort “meskipun tamu kami kebanyakan non-muslim, sementara yang muslim lebih jarang bertamu, namun kami tetap memasang penunjuk arah kiblat di setiap kamar karena itu adalah prosedur tetap, apalagi setelah ada Perda No. 2 Tahun 2016. Jangankan hotel yang berada di daerah seribu masjid, di hotel-hotel daerah yang mayoritas non-muslim pun tetap memasang itu."

Sebagai bagian dari wilayah pulau yang dijuluki Pulau Seribu Masjid, terpasangnya tanda arah kiblat bukanlah semata-mata karena mengikuti Peraturan Daerah tentang pariwisata halal, akan tetapi, penanda arah kiblat tersebut memang sudah melekat pada jati diri icon Pulau Seribu Masjid itu sendiri. Andaipun Perda Wisata Halal itu tidak pernah terbit, penanda kiblat harus tetap ada.

2). Informasi Masjid Terdekat.

Ada dua buah masjid yang berada di Gili Trawangan, yaitu bagian utara Masjid Baiturrahman dan bagian selatan Masjid Nurul Istiqomah. Secara posisi, kedua masjid ini berada pada bagian sisi timur Gili Trawangan yang merupakan kawasan terpadat. Sementara di sisi barat tidak terdapat bangunan masjid, pada sisi sebelah barat ini hanya dipenuhi bangunan-bangunan hotel dan resort. Selain dua buah masjid, di Gili Trawangan juga terdapat sebuah mushalla di sisi sebelah utara yang diberi nama Musalla Raudatul Jannah.

Masing-masing fasilitas tempat ibadah tersebut, baik masjid maupun musalla memiliki penunjuk arah yang terpasang pada ujung jalan menuju fasilitas tersebut. Penunjuk arah tersebut dipasang di setiap ujung jalan untuk membantu para wisatawan khususnya yang beragama Islam agar dapat menemukan lokasi masjid ter- 
dekat jika telah tiba waktu shalat.

Berbeda dengan beberapa destinasi wisata lain di Pulau Lombok di mana para wisatawan bisa melakukan ritual shalat di manapun ia berada di lokasi wisata, hampir di setiap sudut pulau Gili Trawangan dijejali oleh para wisatawan manca negara dengan busana yang tidak selayaknya digunakan oleh orang muslim sehingga bisa mengganggu kekhusyu'an ketika melakukan ibadah. Oleh karena itu, para wisatawan muslim lebih memilih fasilitas ibadah seperti masjid dan musalla untuk menjalankan ibadah shalat mereka. Di samping sebagai fasilitas ibadah, masjid dan musalla di kawasan Gili Trawangan dimanfaatkan oleh para pelancong muslim untuk beristirahat melepas lelah sebelum melanjutkan aktifitas wisata mereka.

3). Tempat Ibadah Bagi Wisatawan Dan Karyawan Muslim.

Sebagai seorang muslim, para karyawan tentunya membutuhkan tempat khusus untuk menunaikan kewajiban mereka kepada sang khalik. Oleh karena itu, sesuai dengan Peraturan Daerah Nomor 2 Tahun 2016 tentang Wisata halal, semua perusahaan tempat mereka bekerja harus menyiapkan tempat shalat bagi para karyawannya. Bisa berupa musalla, ataupun ruang tertentu yang dijadikan tempat shalat.

Sebagaimana yang disampaikan oleh Ahmad, bahwa kebanyakan tempat bekerja di Gili Trawangan menyiapkan tempat bagi karyawannya untuk melaksanakan shalat, termasuk di Kokomo Resort, perusahaan menyiapkan tempat bagi karyawan muslim untuk menunaikan shalat yang terletak di belakang Resort lengkap dengan tempat berwudlu dan peralatan shalat. Sedangkan untuk para tamu, pihak manajemen menyiapkan sebuah ruangan khusus bagi yang muslim untuk dijadikan sebagai musalla.

Hanya saja, hotel-hotel dan resort di Pulau Gili Trawangan tidak memutar suara azan ketika datang waktu shalat. Para tamu dan karyawan mengetahui waktu shalat telah tiba cukup hanya mendengar suara azan dari dua masjid setempat yang jaraknya memang relatif tidak berjauhan sehingga suara azan bisa didengar dari semua sudut Pulau.

4). Keterangan Tentang Produk Halal/Tidak Halal.

Banyak sekali produk-produk makanan yang tersedia di pasar, warung, supermarket yang kita tidak menemukan kepastian kehalalan dalam kemasannya. Atau terkadang halal namun tidak diproduk dengan baik seperti memproduksi makanan yang tidak bermutu dan tidak bergizi. Banyak juga makanan dengan kandungan bahan-bahan kimiawi yang membahayakan bagi kesehatan. Selain itu terdapat pula yang menjual makanan kadaluarsa dengan kemasan yang mengelabui konsumen. Untuk melindungi para konsumen muslim dari bahaya produk yang membahayakan ini, 
maka pemerintah melalui MUI melakukan labelisasi halal pada produk makanan dan minuman.

Labelisasi halal adalah proses pencantuman tanda halal pada sebuah produk makanan dan minuman dalam kemasan yang dilakukan oleh lembaga yang berwenang yaitu Departemen Kesehatan melalui LPPOM MUI.

LPPOM MUI sebagai pemegang amanat pelayanan perlindungan bagi umat khususnya yang terkait dengan produk-produk makanan, minuman maupun kosmetika. MUI melakukan tugas sertifikasi halal melalui 2 tahap yaitu penelitian ilmiah dengan proses audit yang dilakukan oleh LPPOM-MUI dan penelaahan serta penetapan fatwa dalam aspek syariah oleh para ulama di komisi fatwa MUI. LPPOM MUI sebagai sebuah lembaga professional yang berbasis kompetensi, sehingga para pelaku yang terlibat melakukan sertifikasi harus memiliki kompetensi sesuai dengan persayaratan yang dibutuhkan. Dalam proses sertifikasi halal, lembaga tersebut melibatkan banyak pakar dan tenaga ahli dengan berbagai latar belakang disiplin ilmu yang dibutuhkan (MUI, 2014).

Pelabelan halal terhadap suatu produk makanan sangatlah penting, oleh karena itu dibutuhkan sebuah regulasi serta lembaga yang melakukan sertifikasi dan harus dilaksanakan secara konsekuen agar dapat meyakinkan konsumen muslim, agar tidak merasa ragu atas kehalalan produk makanan yang dikonsumsinya.

Lahirnya Undang-Undang Republik Indonesia Nomor 33 Tahun 2014 Tentang Jaminan Produk Halal menuntut para pelaku usaha untuk melakukan sertifikasi halal atas produk-produknya. Undang-undang ini merupakan tantangan tersendiri sekaligus peluang bagi pagi para pelaku usaha terutama produk makanan dan minuman. Apalagi pada 2019 nanti ditargetkan semua produk makanan harus memiliki label halal. Peraturan Daerah No. 2 tahun 2016 tentang Wisata Halal di NTB adalah breakdown dari Undang-undang No, 33 yang memuat tentang pelabelan halal pada produk makanan.

Tujuan diterapkannya pencantuman label halal pada produk makanan ini sebagaimana disebutkan dalam Pasal 3 UU No. 33 tersebut adalah untuk memberikan kenyamanan, keamanan, keselamatan, dan kepastian ketersediaan Produk Halal bagi masyarakat dalam mengonsumsi dan menggunakan Produk. Di samping itu pula untuk meningkatkan nilai tambah bagi Pelaku Usaha untuk memproduksi dan menjual Produk Halal (UU RI No. 33 Tahun 2014).

Menurut Martoyadi, tidak ada pelabelan halal untuk produk-produk makanan dan minuman di hotel dan resort Gili Trawangan, halal dan haramnya makanan nanti diketahui sendiri oleh konsumen berdasarkan jenisnya tanpa harus ada label. 
Penerapan Perda No. 2 Tahun 2016 Tentang Pariwisata halal khususnya pada poin ini tentu memiliki tantangan tersendiri. Sudah menjadi rahasia umum bahwa hampir semua pelaku usaha perhotelan dan resort di Gili Trawangan tidak bisa melepaskan diri dari produk-produk yang tidak memiliki label kehalalan. Produk-produk tersebut didominasi oleh produk minuman beralkohol dari berbagai merek. Barang-barang tersebut terpampang jelas di sepanjang jalan Pulau Gili Trawangan tanpa harus disembunyikan seperti di beberapa tempat lain di Pulau Lombok.

Salah seorang General Manager hotel menuturkan "untuk standar wisata halal seperti tempat shalat, wudlu' dan arah kiblat kami bisa laksanakan, tapi untuk menghilangkan minuman-minuman berbagai merek ini sepertinya tidak mungkin karena kebanyakan tamu kita sangat butuh dengan barang ini, jika barang ini tidak ada, mereka tidak akan mau bertamu ke tempat ini.

Di cafe-cafe resort Gili Trawangan, para wisatawan dapat menikmati berbagai macam merek minuman yang beralkohol, seperti bier, vodka, Malibu, dan berbagai merek lainnya. Umumnya minuman tersebut diimport dari luar negeri disesuaikan dengan selera pengunjung.

Meski banyaknya tersedia minuman yang tergolong "haram” di hotel dan resort Gili Trawangan, namun tidak serta merta para karyawan ikut menikmati sajian tersebut. Para karyawan dibatasi bahkan tidak diperkenankan oleh pihak managmen untuk berprilaku bebas seperti para wisatawan. Sikap ini diambil untuk mengantisipasi agar para karyawan selalu bekerja profesional. Sebab, jika mereka terjerumus melakukan seperti kebiasaan para tamu, dikhawatirkan akan mempengaruhi kinerja mereka ketika bertugas. Demikian juga mereka dilarang mengkonsumsi obat-obatan terlarang karena bisa merusak nama baik perusahaan.

Berbeda dengan minuman yang ada halal dan ada haramnya, menu makanan yang tersedia di hotel dan resort seputaran Gili Trawangan umumnya adalah merupakan makanan yang halal untuk dikonsumsi. Meskipun tidak ada sertifikasi halal dari LPPOM MUI, namun setidaknya bisa dijamin bahwa makanan-makanan yang tersedia di cafe-cafe Gili Trawangan tidak mengandung unsur-unsur yang diharamkan karena dipasok oleh penduduk setempat dari seputaran Pulau Lombok. Ini bisa dibuktikan dari daftar menu makanan yang disediakan pengelola cafe-cafe yang tidak ada mencantumkan daftar makanan yang diharamkan oleh agama.

\section{5). Tempat Berwudhu Terpisah Antara Laki-Laki dan Perempuan.}

Mengambil air wudlu adalah kegiatan yang dilakukan oleh seorang muslim sebagai syarat sah untuk melakukan ibadah shalat. Mengambil air wudlu bisa dilakukan di manapun asalkan airnya bersih dan sesuai dengan standar syari'at, seperti men- 
cukupi dua kullah, tidak pernah tercampur benda lain yang menyebabkan sifat air berubah. Tempat mengambil air wudlu bisa di sungai, kolam, pancuran, kran, bahkan juga boleh dilakukan di laut.

Tempat berwudlu bagi para wisatawan yang ada di Gili Trawangan umumnya memisahkan antara laki-laki dan perempuan, baik yang berada di fasilitas hotel dan resort maupun di tempat fasilitas beribadah umum seperti masjid dan musalla.

Pemisahan tempat berwudlu antara laki-laki dan perempuan dimaksudkan agar mereka tidak bercampur, khususnya bagi kaum hawa bisa melakukan aktifitas berwudlu secara lebih nyaman. Bagi kaum hawa, aktifitas berwudlu dilakukan pastinya dengan membuka sebagian aurat mereka. Berbeda dengan laki-laki yang dapat lebih leluasa melakukan aktifitas berwudlu.

Pemisahan fasilitas tempat berwudlu antara laki-laki dan perempuan terkadang langsung dengan mendirikan bangunan yang terpisah khusus untuk laki-laki dan khusus untuk perempuan dengan jarak yang cukup signifikan segingga antara mereka tidak terjadi kontak mata apalagi bersentuhan fisik yang menyebabkan wudlu mereka batal. Fasilitas tempat berwudlu seperti ini biasanya terdapat di masjid-masjid besar seperti Masjid Baiturrahman dan Masjid Nurul Istiqomah Gili Trawangan. Fasilitas berwudlu terkadang juga berada dalam satu bangunan dengan membuat tabir pemisah antara laki-laki dan perempuan seperti di Villa Ombak Hotel. Ada juga yang hanya menyiapkan tempat shalat sementara wudlu dilakukan di kamar masing-masing seperti di Cocomo Resort. Namun untuk karyawannya, Cocomo Resort menyiapkan tempat shalat dan wudlu sekaligus yang berada di mes karyawan dengan tidak memisahkan antara laki-laki dan perempuan.

Dari beberapa data lokasi penelitian di atas, ketersediaan fasilitas berwudlu yang memisahkan antara laki-laki dan perempuan bervariasi. Namun secara umum, sebagian besar fasilitas berwudlu tersebut sudah merepresentasikan pemisahan antara kaum lelaki dengan perempuan ketika mengambil air wudlu meskipun tidak bisa sempurna seratus persen.

\section{Wisata Halal Gili Trawangan dalam Pandangan Pelaku Wisata}

1). Respon Pelaku Wisata.

Terbitnya Peraturan Daerah No. 2 Tahun 2016 Tentang Pariwisata Halal di NTB tidak serta merta diterima oleh semua kalangan masyarakat. Beberapa elemen masyarakat baik dari politisi, pelaku wisata, bahkan para tokoh agamapun banyak yang menolak atau mempertanyakan adanya perda ini. Terlebih di beberapa destinasi wisata di NTB peraturan tersebut dianggap mustahil untuk diterapkan. Penolakan terse- 
but ada yang bersifat politis ada pula yang murni menolak karena kesalahpahaman mengenai wisata halal.

Di antara tokoh politik yang tidak setuju atas digulirkannya konsep wisata halal di NTB adalah Bupati Lombok Timur periode 2013-2018. Beliau mengatakan bahwa industri pariwisata tidak perlu ditambahi dengan label-label agama seperti istilah halal. Beliau beralasan bahwa pariwisata adalah sebuah kegiatan foya-foya dan bersenang-senang yang dilakukan oleh wisatawan yang tidak boleh dibatasi oleh peraturan tertentu. Mereka bebas melakukan apa saja seperti telanjang di pinggir pantai, meminum minuman keras, bahkan berbuat mesum di dalam hotel. Oleh karena itu tidak layak wisata diberikan embel-embel halal.

Munculnya peraturan daerah tentang wisata halal tidak membuat semua masyarakat pelaku wisata memiliki respon yang sama. Perbedaan respon itu terjadi lebih banyak disebabkan karena kekurangpahaman mereka tentang pariwisata halal. Masyarakat yang cenderung menolak kehadiran pariwisata halal disebabkan khawatir jika sektor pariwisata konvensional akan mengalami kerugian karena para wisatawan lebih memilih wisata yang berlabel syariah.

Seperti yang diungkapkan oleh Fahrurrozi Gaffar, awalnya sejumlah pengusaha perhotelan menyampaikan kekhawatirannya terhadap penerapan wisata halal di NTB, mereka khawatir jika dengan diterapkannya wisata halal, para tamu yang berasal dari agama non-muslim akan tidak lagi tertarik untuk bertamu dan berwisata ke NTB.

Kekhawatiran pelaku wisata ini sangat beralasan, karena wisatawan terbanyak adalah mereka yang beragama non-muslim. Para pelancong yang berasal dari negara-negara Eropa kerap memadati tempat-tempat wisata di NTB. Di sepanjang pantai Gili Trawangan sendiri seolah merekalah yang memiliki pantai. Menikmati pantai dengan pakaian minim yang sangat kontras dengan budaya masyarakat setempat.

Menurut $\mathrm{H}$. Baharudin, perilaku para wisatawan yang kebanyakan dari eropa di pantai Gili Trawangan memang sangat tidak sesuai dengan nilai-nilai budaya lokal masyarakat di Gili Trawangan, namun hal tersebut tidak begitu saja bisa mengubah budaya lokal yang kental dengan nilai Islamnya. Menurutnya, perilaku tersebut dipandang oleh masyarakat sekitar hanya dari kaca mata bisnis semata; di mana para pelancong tersebut dianggap sebagai instrumen bisnis yang dapat mendatangkan keuntungan dan kesejahteraan bagi warga sekitar.

Bermacam respon yang muncul terkait implementasi Perda No. 2 ini jika diterapkan di Gili Trawangan. Menurut Fahrurrozi Gaffar, implementasi Perda No. 2 Tahun 2016 Tentang Wisata Halal di Gili Trawangan memang sulit, butuh banyak ikhtiar 
untuk mewujudkannya. Mengimplentasikan Perda ini di Gili Trawangan secara utuh dikhawatirkan akan banyak mengorbankan beberapa sisi dari bisnis pariwisata di Gili Trawangan seperti penjualan minuman keras. Ini disebabkan karena salah satu item dalam Perda tersebut adalah tentang makanan yang bersertifikat halal.

Hal senada juga disampaikan oleh Martoyadi, ia mengatakan bahwa untuk di Gili Trawangan Peraturan Daerah Tentang Pariwisata Halal secara utuh tidak bisa diterapkan. Menurutnya, hanya sebagian saja dari peraturan tersebut yang bisa dijalankan di Gili trawangan.

Beberapa item Peraturan Daerah No. 2 Tentang Pariwisata Halal yang dapat diterapkan di Gili Trawangan adalah seperti pemasangan tanda arah kiblat di hotel, sarana tempat shalat dengan semua pendukungnya. Sedangkan yang terkait dengan sertifikasi halal di cafe-cafe dan restoran di Gili Trawangan sangat sulit untuk diterapkan. Seperti yang diutarakan sebelumnya bahwa sertifikasi halal pada restoran dan cafe tersebut dapat menurunkan tingkat hunian hotel dan resort disebabkan karena beberapa kebutuhan para tamu tidak tersedia. Sementara ketersediaan fasilitas dan sarana yang mendukung untuk melaksanakan shalat bagi wisatawan muslim tidaklah dianggap sebagai hal yang menurunkan tingkat hunian karena tidak mengganggu kenyamanan dan kesenangan para wisatawan.

Meskipun Perda No. 2 Tahum 2016 Tentang Wisata Halal sulit diterapkan secara utuh di Gili Trawangan, namun imbas dari meningkatnya jumlah wisatawan yang berkunjung ke NTB sebagai efek dari branding wisata halal sangat membantu bagi peningkatan jumlah wisatawan ke Gili Trawangan. Hal ini sebagaimana disampaikan oleh Saiful Bahri:

“memang di Gili Trawangan sangat sulit untuk menerapkan Perda No.2 tahun 2016 Tentang Wisata Halal, tapi kenaikan jumlah wisatawan yang berkunjung ke NTB setelah ada istilah wisata halal justru menyebabkan melonjaknya jumlah wisatawan yang berkunjung ke Gili Trawangan".

Diakui atau tidak, banyaknya wisatawan yang memasuki Pulau Gili Trawangan tidak lepas dari branding wisata halal yang digulirkan oleh pemerintah propinsi Nusa Tenggara Barat. Sejak 2015 lalu, magnet wisata Lombok Sumbawa sedang naik daun dan mulai dikenal oleh berbagai negara di dunia. Laju pertumbuhan pariwisata tersebut juga dirasakan oleh pelaku industri wisata.

Respon yang sangat berbeda diungkapkan oleh direktur Kayangan Tour Furqon Ermansyah. Dia mengatakan, untuk menggaet banyaknya wisatawan yang datang ke Lombok khususnya Gili Trawangan tidak perlu ada branding wisata halal. Apalagi dengan adanya Perda No. 2 Tahun 2016 Tentang Wisata Halal sangat tidak layak diterap- 
kan di Kawasan Wisata Gili tersebut. Diberlakukannya Perda Syari'ah di Gili Trawangan justru bisa menurunkan jumlah kunjungan wisatawan yang datang ke sana. Bahkan munculnya Perda Wisata halal menurut dia merupakan suatu kecerobohan, bukan hanya merugikan para pelaku industri wisata di Gili Trawangan, melainkan juga akan merugikan NTB secara umum.

Lebih lanjur Furqon Ermansyah menjelaskan bahwa NTB khususnya Lombok sejak dulu sudah memiliki nilai-nilai keislaman yang tinggi, muslim mayoritas di NTB tidak bisa dijadikan alasan untuk menerbitkan sebuah Perda Syari'ah. Baginya, nilainilai keislaman yang berkembang sejak lama di daerah NTB sudah cukup menjadi jaminan kehalalan semua fasilitas sarana dan pendukung pariwisata tanpa harus ada Perda syari'ah. Perda Syari'ah hanya bisa menaikkan jumlah wisatawan hanya sesaat saja, bisa satu sampai lima tahun, namun setelah itu akan terjun bebas karena peraturan daerah tersebut menyebabkan kejenuhan bagi wisatawan. Di samping itu pula menurut Furqan, Perda Wisata Halal bagi Nusa Tenggara Barat justru menjatuhkan martabat masyarakat muslim di daerah ini. Dengan adanya sertifikasi halal untuk restoran hotel misalnya, orang akan berpersepsi seolah di Nusa Tenggara Barat itu terlalu banyak makanan yang tidak halal sehingga diharuskan untuk melakukan sertifikasi restoran. Demikian juga mewajibkan hotel dan pengelola destinasi wisata untuk menyiapkan sarana dan fasilitas shalat, seolah di Nusa Tenggara Barat fasilitas tersebut langka dan sulit ditemui, padahal Lombok dikenal dengan julukan Pulau Seribu Masjid di mana di setiap jengkalnya kita dapat menemukan masjid dengan mudah. Oleh karena itu, membuat peraturan yang mengatur sarana dan fasilitas shalat adalah suatu hal yang lucu karena semua fasilitas dan sarana tersebut sudah tersedia sebelumnya tanpa harus ada Perda yang mengatur, itu sama saja dengan mengajari ikan berenang.

Furqan Ermansyah sebenarnya bukan tidak setuju dengan istilah wisata halal. Dia menegaskan bahwa sebagai seorang muslim dirinya sangat setuju dan bangga dengan penerapan wisata halal. Wisata halal yang dimaksud oleh Furqan adalah wisata halal yang diterapkan di wilayah atau negara yang benar-benar membutuhkan konsep wisata halal seperti Bali, NTT, Papua. Atau negara-negara yang memiliki populasi muslim yang nukan mayoritas seperti Thailand, Jepang, Amerika Serikat dan lain-lain. Menurutnya, di wilayah dan negara-negara tersebut sangat dibutuhkan konsep wisata halal terutama untuk mengakomodir kebutuhan para wisatawan muslim.

Munculnya Peraturan Daerah Tentang Wisata Halal ini juga menurut Furqan, justru lambat laun bisa berdampak buruk bagi perkembangan wisata NTB. Untuk saat ini mungkin branding wisata halal dapat meningkatkan kunjungan wisatawan ke NTB. Peningkatan ini sifatnya hanya sesaat karena wisatawan yang belum pernah ke NTB akan menduga bahwa berwisata di NTB itu sangat bernuansa islami dengan 
destinasi wisata dan akomodasi yang berbeda dari daerah yang lain. Namun setelah mereka mengetahui bahwa di NTB sebenarnya tidak jauh berbeda dengan pariwisata di wilayah yang lain, merekapun akan merasa bosan berwisata ke NTB. Selanjutnya posisi pariwisata NTB akan kembali ke keadaan seperti sebelum adanya Perda Wisata Halal atau bahkan bisa saja lebih rendah.

2). Konsep Wisata Pantai Syari'ah Sebagai Penyeimbang Wisata Gili Trawangan.

Perspektif yang berbeda muncul dari Ahmad, General Manager Coco-mo Resot Gili Trawangan. Ia berpendapat bahwa implementasi Perda No. 2 Tahun 2016 Tentang Wisata Halal di Gili Trawangan sangatlah sulit. Diperlukan sebuah terobosan baru agar peraturan daerah tersebut bisa diterapkan di kawasan Gili bukan hanya di Gili Trawangan. Selama ini, Gili Trawangan menawarkan model wisata pantai yang sangat konvensional dengan sajian budaya barat yang kontras dengan budaya ketimuran.

Lahirnya Peraturan Daerah No. 2 tahun 2016 Tentang Wisata Halal yang ditandatangani langsung oleh Gubernur Nusa Tenggara Barat yang notabene adalah tokoh agama yang religus sehingga Perda tersebut diharapkan dapat merubah mindset wisata pantai yang identik dengan ketelanjangan menjadi wisata pantai yang islami dengan menampilkan nilai-nilai kesopanan dan tidak mengumbar aurat. Oleh karena itu, sudah selayaknya ditetapkan sebuah pantai yang berlabel syari'ah atau wisata pantai halal.

Menurut Ahmad, Gili Meno atau Gili Air bisa saja disulap menjadi destinasi wisata pantai syari'ah dengan menerapkan Perda No. 2 Tahun 2016 secara utuh di sana, sementara tetangganya Gili Trawangan tidak berubah namun tetap seperti situasinya sekarang ini.

Konsep wisata pantai syariah ini sudah banyak dikembangkan di beberapa daerah di antaranya seperti Banyuwangi. Wisata pantai syari'ah di Banyuwangi dilaunching langsung oleh Bupati Banyuwangi Azwar Anas pada tanggal 2 Pebruari 2017 dengan memilih pantai di Pulau Santen. Letak pantai yang strategis di sisi timur Kota Banyuwangi, tepatnya di sebelah selatan kawasan Pantai Boom. Pulau Santen yang masuk wilayah Kelurahan Karangrejo diharapkan bisa menjadi salah satu destinasi wisata unggulan di Banyuwangi (Susanti, 2018).

Jika nantinya terwujud sebuah wisata pantai syari'ah dengan mengambil salah satu Gili di kawasan Desa Gili indah, maka diharapkan bisa menjadi penyeimbang situasi kebatinan dengan wisata pantai di Gili Trawangan. Penyeimbang di sini maksudnya apabila wisatawan jenuh dan bosan dengan sajian wisata pantai di salah satu Gili, misalnya Gili Trawangan yang konvensional, maka ia bisa dengan mudah mencari situasi lain yang lebih yang menetralisirnya karena jaraknya yang berdekatan. 


\section{Perda Wisata Halal Hanya Untuk Wisata Kota (Urban Tourism)}

Implementasi Peraturan Daerah No. 2 tahun 2016 Tentang Wisata Halal pada destinasi wisata pantai seringkali menjadi diskusi hangat di kalangan pemerhati wisata. Pada umumnya konsep wisata pantai digambarkan sebagai kegiatan menikmati pantai dengan hanya berpakaian minim setengah telanjang baik untuk berenang di laut maupun dengan berjemur di pinggir pantai. Alasan inilah yang kemudian memunculkan persepsi bahwa konsep wisata halal sangat tidak cocok diterapkan untuk wisata pantai khususnya seperti di Gili Trawangan.

Seperti yang disampaikan oleh Martoyadi, Perda Wisata Halal kurang cocok diterapkan di Gili Trawangan. Perda tersebut lebih tepatnya diterapkan dalam konsep wisata kota di mana para wisatawan menikmati obyek wisata tanpa harus menampakkan aurat seperti pada wisata pantai (Martoyadi, 2018).

Wisata kota adalah suatu kegiatan untuk menarik wisatawan domestik maupun mancanegara dengan menyediakan akomodasi dan program kunjungan ketempat yang menjadi daya tarik kota tersebut (Inskeep, 1991).

Kota dipandang sebagai suatu proses kompleks yang terkait dengan budaya, gaya hidup, dan sekumpulan permintaan yang berbeda terhadap liburan dan perjalanan. Kota merupakan destinasi dengan multimotivasi, tidak seperti resor-resor pada umumnya (Law, 1991). Orang-orang datang ke suatu kota untuk berbagai tujuan: bisnis, kegiatan hiburan dan rekreasi, mengunjungi keluarga dan kerabat, atau urusan pribadi lainnya. Seringkali, mereka mengunjungi kota untuk lebih dari satu alasan. Orang yang pergi ke suatu kota untuk berbisnis, menyempatkan diri untuk mengunjungi museum, masjid, balai kota, monument kota, alun-alun, pusat kuliner, pusat perbelanjaan dan lain-lain.

\section{Perda Wisata Halal Harus Dibreakdown ke dalam Perda pada Masing-masing Kabupaten/Kota}

Nusa Tenggara Barat sebagai Propinsi pertama dan satu-satunya di Indonesia yang memiliki Peraturan Daerah (Perda) tentang pariwisata halal. Peraturan Daerah ini dirumuskan oleh DPRD NTB untuk menguatkan branding pariwisata halal yang kini menjadi icon provinsi tersebut. Ruang lingkup pengaturan Pariwisata Halal dalam Perda ini mencakup destinasi, pemasaran dan promosi, industri, kelembagaan, pembinaan, pengawasan dan pembiayaan.

Diversitas destinasi dan atraksi wisata di NTB membuat Peraturan Daerah ini sulit diimplementasikan ke seluruh lini wisata NTB. Masing-masing kabupaten memiliki tampilan wisata dan suguhan atraksi wisata yang relatif berbeda sehingga diperlukan 
breakdown Perda tersebut sesuai dengan kebutuhan di setiap kabupaten/kota. Masing-masih wilayah di NTB tidak bisa dipaksa untuk mengimplementasikan Peraturan Daerah Tentang No. 2 Tahun 2016 Tentang Wisata Halal yang dibuat oleh pemerintah provinsi karena memiliki kebutuhan yang berbeda seperti antara Kota Mataram dengan Gili Trawangan. Khusus di Gili Trawangan, sudah ada awig-awig Desa Gili Indah yang mengatur kegiatan pariwisata di kawasan itu. Maka breakdown peraturan daerah tentang wisata halal hanya tinggal menyesuaikannya dengan awig-awig tersebut. Apa yang masih kurang pada awig-awig desa dilengkapi dengan Perda atau Perbup, dan bagian yang sudah lengkap akan saling menguatkan.

Menurut Wakil Direktur Politeknik Pariwisata Lombok, Farid Said, Peraturan Daerah No. 2 Tahun 2016 Tentang Pariwisata Halal yang dikeluarkan oleh Pemerintah Provinsi NTB harus dibreakdown oleh semua kabupaten/kota di NTB sesuai dengan kebutuhannya (Said, 2019). Dengan membuat peraturan daerah yang dibreakdown dari peraturan di atasnya akan lebih memudahkan kabupaten/kota dalam mengelola pariwisata halal di wilayahnya.

\section{SIMPULAN}

Penerapan wisata halal di Gili Trawangan Lombok Utara lebih menekankan pada tersedianya standar industri halal daripada mengubah perilaku wisatawan yang sebagian besar tidak sesuai dengan dengan nilai etika islami. Namun ketersediaan fasilitas halal tersebut juga tidak sepenuhnya tersedia karena kawasan wisata Gili Trawangan sudah lama menerapkan konsep wisata konvensional. Sebagian pelaku wisata menganggap tidak perlu ada upaya untuk menerapkan konsep wisata halal di kawasan Gili Trawangan. Menurutnya, menerapkan konsep halal tourism di kawasan Gili Trawangan justru akan membunuh aktifitas pariwisata di tempat itu. Karena jika konsep wisata halal diterapkan di sana, maka para wisatawan mancanegara yang sudah terbiasa datang ke Gili Trawangan akan merasa tidak nyaman lagi karena beberapa barang kebutuhan mereka sudah tidak bisa didapatkan lagi di tempat ini.

\section{PUSTAKA ACUAN}

Aan Jaelani, Industri Wisata Halal di Indonesia: Potensi dan Prospek (https://mpra. ub.uni-muenchen.de/76237/).

Budhy Munawar Rachman. (2011). Membela Kebebasan Beragama Percakapan tentang Sekularisme, Llberalisme, dan Pluralisme (Buku 1). Jakarta: Yayasan Abad Demokrasi.

Dani Muhtada, Perda Syariah di Indonesia: Penyebaran, Problem, dan Tantangannya, 
Artikel Pengukuhan Guru Besar Fakultas Hukum Universitas Negeri Semarang.

Fahad Salim Bahamman. (2012). Panduan Wisatawan Muslim. Jakarta: Pustaka Al-Kautsar.

Fitri Kartini. (2013). Faktor-faktor yang mempengaruhi Keputusan Tamu Hotel dalam Menggunakan Layanan Namira Hotel Syari'ah Yogyakarta, UIN Yogyakarta.

Hasanain Juaini. (2016). Perspektif Islam dan Budaya Menuju Wisata Syari'ah di NTB, disampaikan pada Seminar Nasional Wisata Halal di Kampus IPDN NTB.

Husen Umar. (2004). Metode Penelitian Untuk Skripsi dan Tesis. Jakarta: PT. Raja Grafindo Persada.

Inskeep, E. (1991). Tourism planning: an integrated and sustainable development approach. Van Nostrand Reinhold.

Inu Kencana. (2009). Pengantar Ilmu Pariwisata. Jakarta: Mandar Maju.

Irwanto. (2007). Focus Group Discussion: Sebuah Pengantar Praktis Jakarta: Yayasan Obor Indonesia.

Jaelani, A., Setyawan, E., \& Hasyim, N. (2016). Religious Heritage Tourism and Creative Economy in Cirebon: The Diversity of Religious, Cultures and Culinary. Muncen: Journal of Social and Administrative Sciences.

Jafari, J., \& Scott, N. (2014). Muslim world and its tourisms. Annals of Tourism Research.

Lalu Adi Permadi. (2018). Persepsi Dan Sikap Masyarakat Terhadap Rencana Dikembangkannya Wisata Syariah (Halal Tourism) Di Provinsi Nusa Tenggara Barat. Jurnal Amwaluna, Vol. 2 No.1.

Law. C.M. (1991). Tourism and urban revitalization, East Midland Geographer Vol.14 No.1/2.

Lexy J. Maleong. (1990). Metode Penelitian Kualitatif. Bandung: Remaja Rosdakarya.

M. Djunaidi Ghony \& Fauzan Almanshur. (2012). Metodologi Penelitian Kualitatif. Yogyakarta: Ar-Ruzz Media.

Mardani. (2015). Aspek Hukum Lembaga Keuangan Syariah di Indonesia. Jakarta: Prenada Media.

Misran. (2003). Pelaksanaan Syari'at Islam Di Aceh Analisis Kajian Sosiologi Hukum, Legitimasi Jurnal Hukum Pidana dan Politik Hukum, Vol.1 No. 2.

Muhammad Tahwin. (2003). Pengembangan Obyek Wisata Sebagai Sebuah Industri, Jurnal Gema Wisata.

Mulyani. (2007). Faktor Situasi Respon Kontekstual. Jakarta: Grafika.

Nawal Ika Susanti, Respon Masyarakat Terhadap Pantai Syariah Pulau Santen di Kelurahan Karangrejo Banyuwangi, Jurnal Istiqro: Jurnal Hukum Islam, Ekonomi dan Bisnis, Vol.4 / No.1: 18-31, Januari 2018, h. 18-31.

Noeng Muhadjir. (1996). Metodologi Penelitian Kualitatif . Yogyakarta: Rake Sarasin. 
Nur Rohim Yunus. (2015). Penerapan Syariat Islam Terhadap Peraturan Daerah dalam Sistem Hukum Nasional Indonesia, Hunafa: Jurnal Studia Islamika, Vol. 12, No. 2.

Republika Online.

Ronny Kountur. (2004). Metode Penelitian. Jakarta: Penerbit PPM.

Samori, Z., Md Salleh, N.Z. \& Khalid, M.M, Current Trends in Halal Tourism: Cases on Selected Asian Countries. Tourism Management Perspectives. http:// dx.doi.org/10.1016/j.tmp.2015.12.011., 2016 :132).

Sarwono. (1998). Teori Teori Psikologi Sosial. Jakarta : Raja Grafindo Persada.

Unggul Priyadi dkk. (2014). Potensi Pengembangan Desa Wisata Berbasis Syari'ah di Kabupaten Sleman, DPM UII Yogyakarta.

W. Gulo, Metodologi Penelitian (Jakarta : Gramedia Widiasarana Indonesia, 2002).

Hery Sucipto dkk, Wisata Syari'ah.

http://febi.walisongo.ac.id.

http://simas.kemenag.go.id

https://halallifestyle.id.

https://medium.com. 